\title{
Burn drug made from ozonated vegetable oil mixture with white tumeric and cassava leaves extract
}

\author{
Farah Moulydia, Nabila Salsabila, Ria Kusuma Dewi, Adinda Nirmala, Setijo Bismo* \\ Chemical Engineering Department, Universitas Indonesia, Kampus Baru UI Depok, Depok 16424, Indonesia
}

\begin{abstract}
This research aims to create a burn treatment performed with ozonation process from a mixture of vegetable oil and added extracts of herbal ingredients. Ozonation on vegetable oils proven to kill bacteria and safe for the body. Ozonated vegetable oil produced from the ozone reactor batch process by doing a variety of extraction mixture to Oleozon ${ }^{\circledR}$ and vegetable oils. Then the results of ozonation is added extracts of herbal ingredients that cassava leaves and white turmeric to increase effectiveness in killing bacteria. Cassava leaves have anti-inflammatory agent, namely Vitamin C. While white turmeric Curcuma zedoaria have substance, which of the two compounds can inhibit and kill bacteria. The quality of ozonated oil (Oleozon ${ }^{\circledR}$ ) analytically were tested by the method of iodine number, acid number, peroxide number, and FTIR. Ozonation increased the peroxide and acid values for both oils, the increase being higher for mixture of coconut oil and soybean oil. The results of such mixing is then tested in bacteria to determine their effectiveness in killing the bacteria. The best ozonation condition is in an increase of $386,85 \%$ acid value, peroxide value about $102,91 \mathrm{meq} / \mathrm{kg}$ oil, and decrease in iodine number up to $21 \%$. The result showed that under these conditions, ozonized oil has an antiseptic effect against Staphylococcus aureus. The final results of this study are expected to be a new innovation in the healing of skin wounds caused by burns as an anti-inflammatory that is effective, safe, and environmentally friendly.
\end{abstract}

\section{Introduction}

Burns are damages to our body tissues caused by heat, chemicals, electricity, sunlight or radiation. Besides, burns can cause swelling, blistering, leaving scars and can cause serious shock. They can also cause infections because they damage the protective layer of the skin. Bacteria that are often the cause of infection in burns are: Streptoccoccus pyogenes, Pseudomonas aeruginosa, Proteus sp, Klebsiella spp, Seratia and Staphylococcus aureus.

The ozonated vegetable oils or Oleozon ${ }^{\circledR}$ have been shown to have antibacterial and antifungal capabilities in food applications, cosmetics and pharmaceutical industries. The reaction of ozone with vegetable oils produces Criegee ozonide, hydroperoxide, and aldehyde products [2]. The research on the ozonated vegetable oils used as medicine in humans does not indicate a secondary reaction.

From the results of research on the characteristics of the ozonated vegetable oil [3] it can be concluded that soybean oil and coconut oil also have the potential to be used as a vegetable oil due to its high unsaturated fat content. In addition, mixing vegetable oil with natural ingredients can also be done to increase the effectiveness of the oil. Selected herbal ingredients are white turmeric and cassava leaves. Both of these herbal ingredients proved to have substances that can be antiinflammatory in skin wounds. Therefore, in this study used extracts of cassava leaves and white turmeric to be mixed into a mixture of coconut oil and soybean oil.

\section{Methodology and Results}

\subsection{Methodology/Experimental}

This study uses the main component of ozonator as an ozone-producing tool to applied in the ozonation process of vegetable oil mixture. The ozonation reaction of the oil will occur in a batch reactor equipped with a $4 \mathrm{~L} / \mathrm{min}$ air flow rate and a coolant to keep the reaction temperature at $25^{\circ} \mathrm{C}$. At this stage the ozonation of vegetable oil is done continuously for 72 hours to see the relationship between the length of time ozonation with the resulting anti-bacterial effects. The vegetable oil mixture will be ozoneated with concentrations of the oil to be varied.

After oil ozonation, herbal extraction is performed. This stage aims to produce herbal plant extracts that are cassava leaves and white turmeric. These two herbs will be macerated using IPA and Hexane solvents for 5 days and stirring every 4 hours. After obtaining the extract by evaporating, the extract will be mixed with the ozonated vegetable oil to add antibacterial properties.

The test method used is the test of iodine number, acid number, peroxide number, FT-IR, and stability test of Oleozon $\AA$. Iod number to know the amount of double bond in oil. Acid number to indicate the amount of free fatty acids present in the oil. Peroxide numbers to show the level of oxidation of ozone to fatty acids. Then for FT-IR to find out the differences in functional groups that increase or decrease during preoccupation

*Corresponding author: sbismo@che.ui.ac.id 
and after the diozonation. As well as stability test Oleozon ${ }^{\circledR}$ for a month at room temperature. This test is performed to determine the success of ozonation, based on changes in the physical and chemical properties of each of the ozonated vegetable oils.

This stage is the stage of addition of vegetable oil into the culture of bacteria that have been prepared before then seen the ability of bacterial disinfection qualitatively in the form of visual observations with the ratio of bacterial culture conditions before and after addition. In this method also can see the mechanism of activity of the ozonated vegetable oil against destruction and inhibition of bacterial cell wall and become bacterial disinfectant.

\subsection{Results and Discussions}

Based on Table $1 \&$ Figure 1 , it can be seen that on all variations of pressure, the ozonated soybean oil (SBO) has decreased the iodine number so it can be inferred that the combined design ozonator succeeds in attacking and lowering the double bond on soybean oil.

The highest decrease in iodine number is in the ozonation process of pure coconut oil (CO) which changes up to $21 \%$ during ozonation process. This indicates that in this condition, the double bond reaction by ozone to produce ozonide is better than in both variations of other oil mixtures. So that pure coconut oil can be an alternative to soybean oil as well.

Table 1. Iodine Number of Ozonated Oil

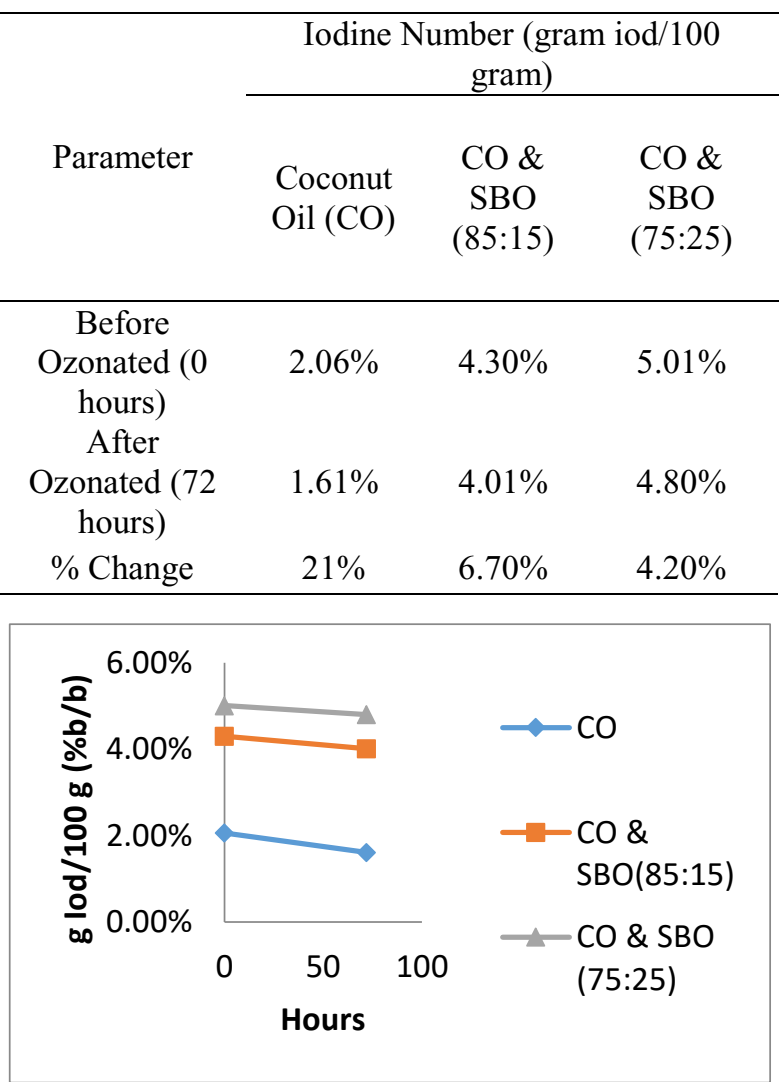

Figure 1. Iodine Number of Ozonated Oil
Based on the available data in Figure $2 \&$ Table 2, it can be seen that the acid number of oil after the diozonation has increased, it seems that the ozonation in this research was successful. Increasing the acid number can indicate that ozonation is successful. The increase in acid numbers is triggered by increased peroxide decomposition and oxidation of aldehydes to carboxylic acids during the ozonation reaction

Table 2.Acid Number of Ozonated Oil

\begin{tabular}{cccc}
\hline & \multicolumn{3}{c}{ Acid Number (mg KOH/g oil) } \\
\cline { 2 - 4 } Parameter & $\begin{array}{c}\text { Coconut } \\
\text { Oil (CO) }\end{array}$ & $\begin{array}{c}\text { CO \& } \\
\text { SBO } \\
(85: 15)\end{array}$ & $\begin{array}{c}\text { CO \& } \\
\text { SBO } \\
(75: 25)\end{array}$ \\
\hline $\begin{array}{c}\text { Before Ozonated (0 } \\
\text { hours) }\end{array}$ & 0.2104 & 0.8377 & 0.3645 \\
$\begin{array}{c}\text { After Ozonated (72 } \\
\text { hours) } \\
\text { \% Change }\end{array}$ & 0.8131 & 1.6423 & 0.7678 \\
\hline
\end{tabular}

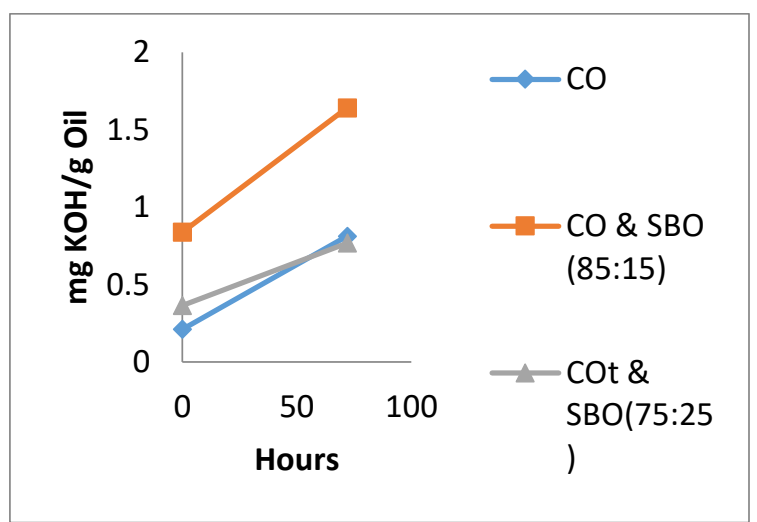

Figure 2. Acid Number of Ozonated Oil

The resulting peroxide acts as an oxidizing agent in lowering the growth factor of Staphylococcus aureus bacteria. The higher the reaction pressure, it allows rapid collision between ozone and soybean oil fatty acid molecules. This ozone will quickly break the double bonds in soybean oil fatty acids, so as to produce the desired ozonolysis product better. The speed of this reaction is also influenced by the stirring system using turbine stirrer, causing high turbulence in the ozonation reaction. Therefore, the pure coconut oil ozonation process is recommended because it has high peroxide numbers. The following Table 3 presents the results of peroxide numbers.

Table 3. Peroxide Number of Ozonated Oil

\begin{tabular}{cccc}
\hline & \multicolumn{3}{c}{ Peroxide Number (meq/Kg Oil) } \\
\cline { 2 - 4 } Parameter & $\begin{array}{c}\text { Coconut Oil } \\
\text { (CO) }\end{array}$ & $\begin{array}{c}\text { CO \& } \\
\text { SBO } \\
(85: 15)\end{array}$ & $\begin{array}{c}\text { CO \& } \\
\text { SBO } \\
(75: 25)\end{array}$ \\
\hline $\begin{array}{c}\text { Before Ozonated } \\
(0 \text { hours }) \\
\begin{array}{c}\text { After Ozonated } \\
(72 \text { hours })\end{array}\end{array}$ & 102.91 & 95.44 & 83.93 \\
\hline
\end{tabular}




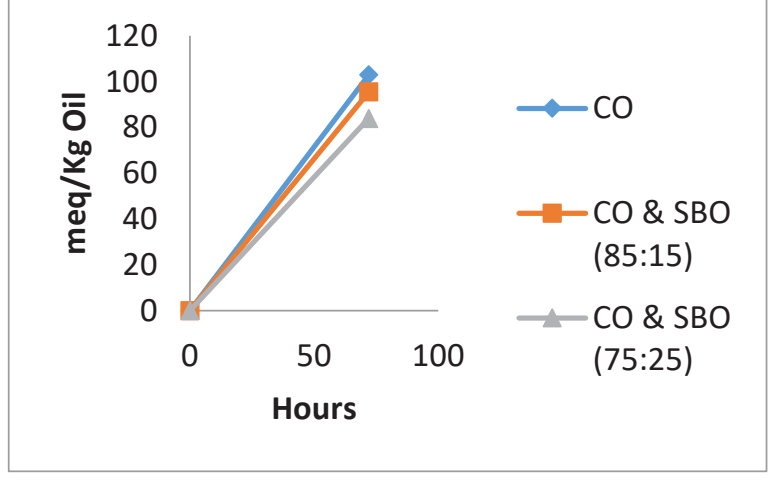

Figure 3. Peroxide Number of Ozonated Oil

Table 4 shows the results of FTIR data on vegetable oil before and after ozonated on a particular mixture of oils. In the data, it appears that there is an increase and there is some decrease in transmittance percent either in aromatic groups, alkene groups, or carbonyl groups. It shows that the concentration decreases in the bonds $\mathrm{C}=\mathrm{O}, \mathrm{C}=\mathrm{C}$, and $=\mathrm{C}-\mathrm{H}$ when an increase in transmittance occurs. Increased transmittant percent indicates that there is a release of bonding on a large carboxylic acid, so the greater the percent increase in transmittance, the more acidic the $\mathrm{pH}$ resulting from ozonated soybean and the higher the acid number obtained.

Then for the bacterial disinfection test it is necessary to know how effective the mixed sample of the ozonated vegetable oil with herbal extract can inhibit the growth of Staphylococcus aureus bacteria.

In the samples of the ozonated vegetable oils indicated a magnitude of inhibit zone of $7.93 \mathrm{~mm}$. That is, the length of time ozonation affects the effectiveness of the ozonolysis product as an antiseptic. 72 hours of ozonation time is a good time in the ozonolysis reaction of soybean oil.

Table 4. FTIR Analysis Results

\begin{tabular}{|c|c|c|c|c|c|c|}
\hline \multirow[b]{2}{*}{ Sample } & \multicolumn{2}{|c|}{$\begin{array}{l}\text { Alkena Bond } \\
\qquad(C=C)\end{array}$} & \multicolumn{2}{|c|}{$\begin{array}{l}\text { Aromatic Bond } \\
\quad(=\mathrm{C}-\mathrm{H})\end{array}$} & \multicolumn{2}{|c|}{ Karbonil $(C=\mathbf{O})$} \\
\hline & $\% \mathrm{~T}$ & $\begin{array}{l}\text { Wavel } \\
\text { ength } \\
\left(\mathrm{cm}^{-1}\right)\end{array}$ & $\% \mathrm{~T}$ & $\begin{array}{l}\text { Wavel } \\
\text { ength } \\
\left(\mathrm{cm}^{-1}\right)\end{array}$ & $\% \mathrm{~T}$ & $\begin{array}{l}\text { Wavel } \\
\text { ength } \\
\left(\mathrm{cm}^{-1}\right)\end{array}$ \\
\hline $\begin{array}{l}\text { CO } \\
\text { (Blanco } \\
\text { ) }\end{array}$ & 86.298 & \multirow{6}{*}{1500} & 88.791 & \multirow{6}{*}{720} & 57.243 & \multirow{6}{*}{1700} \\
\hline $\begin{array}{l}\text { Ozonat } \\
\text { ed CO }\end{array}$ & 89.356 & & 90.794 & & 66.959 & \\
\hline $\begin{array}{l}\mathrm{CO} \mathrm{\&} \\
\text { SBO } \\
(85: 15) \\
\text { Blanco }\end{array}$ & 86.376 & & 87.668 & & 57.962 & \\
\hline $\begin{array}{l}\text { Ozonat } \\
\text { ed } \\
\text { CO \& } \\
\text { SBO } \\
(85: 15)\end{array}$ & 86.31 & & 88.003 & & 57.947 & \\
\hline $\begin{array}{l}\mathrm{CO} \mathrm{\&} \\
\text { SBO } \\
(75: 25) \\
\text { Blanco }\end{array}$ & 86.356 & & 87.029 & & 58.331 & \\
\hline $\begin{array}{l}\text { Ozonat } \\
\text { ed } \\
\text { CO \& } \\
\text { SBO } \\
(75: 25)\end{array}$ & 86.246 & & 87.136 & & 58.467 & \\
\hline
\end{tabular}

Table 5. FTIR Analysis Results

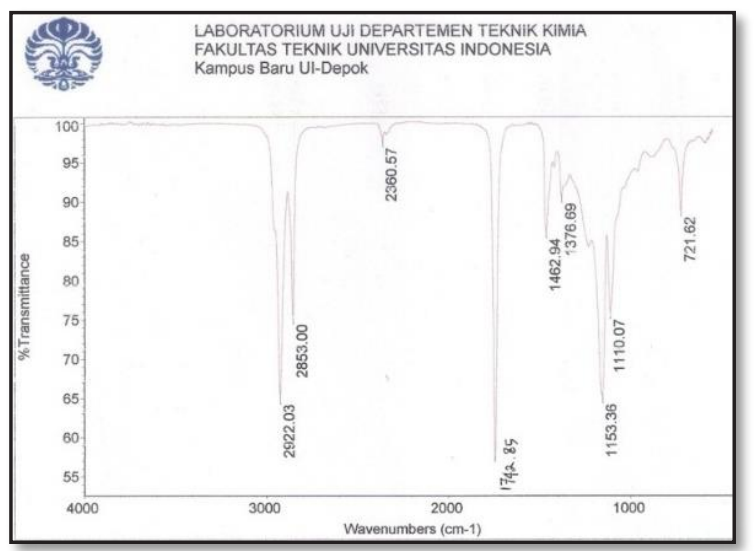

\section{Conclusion}

The optimum temperature for ozonation of coconut oil was obtained at $25^{\circ} \mathrm{C}$ with optimum ozonation time for 72 hours and flow rate of $4 \mathrm{~L} / \mathrm{min}$. Oleozon $\AA$ in the form of oil has increased peroxide number as much as $102,91 \mathrm{meq} / \mathrm{Kg}$ Oil, increase in acid number of $386,85 \%$, and decrease the amount of iodine equal to $21 \%$. The ability of Staphylococcus aureus bacterial inhibition against a mixture of Oleozon ${ }^{\circledR}$ with a positive 72 hour herbal extract can inhibit bacteria.

The authors acknowledge Universitas Indonesia and PITTA program for the financial support. We are also thankful to AKA Bogor and Fakultas Farmasi Universitas Pancasila for the instruments to characterize the Oleozon ${ }^{\circledR}$.

\section{References}

1. Almeida, Nathalia $\mathrm{R}$ de, Adilson Beatriz, Ana Camila Micheletti, dan Eduardo J. de Arruda. Oozonized Vegetable Oils and Ttherapeutic Properties: A Review. Campo Grande: Orbital Eletronic Journal of Chemistry. (2012).

2. Anonymous. Top Types of Burn Wounds and How to Care For Them, [Online]. Avaiable: http://www.advancedtissue.com/top-types-burnwounds-care/ (Akses : 14 September 2016). (2013).

3. Bismo, Setijo. Sintesis Biodiesel dengan Teknik Ozonasi: Ozonolisis Etil- Ester Minyak Sawit Sebagai Suatu Bahan Bakar Mesin Diesel. Alternatif. Depok: Chemical Engineering UI. (2005).

4. Diaz, Maritza F., Dayan Gil, Barbara Manet, Magali Gomez, Eliane T. Sousa, Marcia C. Da C. Veloso, pedro Aa. De P. Pereira, Solange Pizzolatto, Antonio S. Mmangrich, Angelo C. Pinto, Jailson B. De Andrade. Physicochemical Characterization of Ozonated Sunflower Oil Obtained by Different Procedures. Cuba: Ozone Research Center. (2012).

5. Sadowska, Justyna et al. Characterization of Ozonated Vegetable Oil by Spectroscopic and 
Chromatographic Methods. Ireland: Elsevier. (2007).

6. Sechi. Antibacterial Activity of Ozonated Sunflower Oil (Oleozon $®)$. Journal Application Microbiology. 90. 279-284. (2001).

7. Tjitrosoepomo, Gembong., Taksonomi Tumbuhan Obat-obatan, Gadjah mada University Press, Yogyakarta. (2005),

8. USDA. Soybean Research Advisory Institute. United States: Departement of Aglicultur. (2015). 